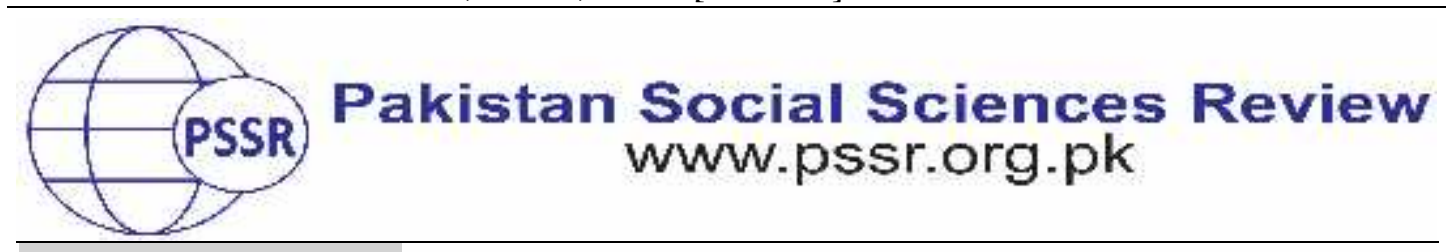

RESEARCH PAPER

\title{
Relationship between Man and Nature in Paulo Coelho's Alchemist: An Ecocriticial Study
}

\section{Ramsha Pervaiz $^{1}$ Dr. Mushtaq Ahmad ${ }^{2 *}$}

1. Research Scholar, Department of English, Riphah International University Faisalabad, Punjab, Pakistan

2. Assistant Professor, Department of English, University of Sahiwal, Punjab, Pakistan

\begin{tabular}{|c|c|}
\hline PAPER INFO & ABSTRACT \\
\hline Received: & The study is an attempt to examine the aspects of the \\
\hline August 10, 2021 & relationship between human beings and nature through the \\
\hline Accepted: & Ecocritical study of Paulo Coelho's novel Alchemist. Through \\
\hline November 11, 2021 & the application of the theory of Ecocriticism, the study explores \\
\hline Online: & the role of nature in the lives of human beings and their success. \\
\hline November 14, 2021 & The study deals with the importance of earth and nature and \\
\hline Keywords: & shows that without nature our life is nothing; without nature \\
\hline $\begin{array}{l}\text { Alchemist, } \\
\text { Ecocritical }\end{array}$ & no one can achieve one's goals. Ecocriticism throws light on the \\
\hline Study, & way all the creations of universe have rights and how the \\
\hline Ecocriticism, & ure influences each \\
\hline Man and Nature & description of friendly behaviour of nature \\
\hline $\begin{array}{l}* \text { Corresponding } \\
\text { Author }\end{array}$ & gs depend on it for everything. It plays a great role in the \\
\hline $\begin{array}{l}\text { drmushtaq@uos } \\
\text { ahiwal.edu.pk }\end{array}$ & $\begin{array}{l}\text { even the sand of desert helps a man to reach his destination. No } \\
\text { one can feel this peace but when a person pays attention on this, } \\
\text { he feels it passionately. }\end{array}$ \\
\hline
\end{tabular}

\section{Introduction}

The present research article is an endeavor to examine the aspects of Ecocriticism and relationship between human beings and nature, through the study of Coelho's (1988) novel named as Alchemist. This study deals with the importance of earth and nature and shows that without nature our life is nothing. Without the help of nature, no one can achieve one's goals. The researchers attempted to examine the importance of the relationship between man and nature from the ecocritical perspective as to how Coelho deals with this relationship of man and nature and how all the elements of nature play their role in the success of a person. The Alchemist is a novel by Paulo Coelho, first published in Portuguese with a title O Alquimista in 1988. This novel has been translated into English by Alan R. Clarke in 1993, and published by Harper Collins Publishers. Then it has end up an international bestseller 
and translated into nearly 70 languages until 2016 and then edited in greater than one hundred fifty international locations.

The Alchemist is an allegorical novel. This novel contains 192 pages. Over the years, there have been film and theatrical adaptations of the work and musical interpretations of it. So many international awards are gained by means of Paulo Coelho for this masterpiece, including the Nielsen Gold E-book Award 2004, for its wonderful income in the United Kingdom retail marketplace, The Corinne worldwide Award 2002 for the quality fiction in Germany, the Golden E-book Award 1995 and 1996 in Yugoslavia, the excellent Grinzane Cavour book Award and Flaiano worldwide Award 1996 in Italy, and the Grand Prix Litteraire of Elle 1995 in France. In step with the professional internet site of $B B C$, this novel recorded as the $94^{\text {th }}$ in the BBC's huge read top one hundred, in April 2003.

There are three reasons why the researchers are interested in analyzing the above-mentioned novel. First reason is because the researchers are interested in the story of philosophy, adventure and vital role of nature. Second reason is because the major character is a simple shepherd boy who is able to achieve his dream for most people is probably impossible. The last reason, this novel brings the researchers close to nature. This is very interesting, because after the perusal of this novel we may know the vital role of nature and its importance in our lives.

There has been a deep bounding between nature and literature for long. Writers and poets have written so many novels and poems to reflect this relationship across the different cultures of the world. Now-a-days, Ecocriticism has become the focus of many disciplines of studies. Ecocriticism has become an interesting theory for literary critics, they study the close relationship of human beings and nature in the texts of writers. According to Ecocritical theory, man is an integral part of nature and its existence. When he acts against nature, there is always an action that is against the wellbeing of human beings.

Ecocriticism is a facilitator between man and nature. It has provided a comfortable, encouraging and civilized environment for a social animal in this universe. As much as the role of nature is concerned, it has a great impact on the lives of human beings and when human beings show any kind of ignorance for nature, they have to pay for it. In the present age, lot of works have been produced on nature and environment in order to create awareness among the people about the significance of nature and its role in the lives of human beings. From the early Greek thought to the present age, the protection of nature always been a point of concern for human beings.

The study of Coelho's novel The Alchemist is analyzing the problems essential for the environmental studies of literature. The present study is actually an effort to present a very wide perspective of the novel The Alchemist by focusing on ecological 
point of views in it. In order to accomplish the task, the ideas of two major ecological theorists, Cheryll Glotfelty and Buell have been utilized. According to Glotfelty (1996) ecocriticism is the study of the association concerning with the literature and the physical atmosphere.

Coelho designed such kind of world in his text in which nature has great importance. He deals with desert, air and sun as the dominant characters that have great significance in the life of Santiago and helps him to find his treasure. In the views of Coelho (1988) "When you really want something, the whole universe conspires it in your favor's" (p. 23).

\section{Literature Review}

Today, Ecocriticism is one of the most deliberated issues. Human beings are considered as social animal from many centuries. Moreover, it is realized in the present century that man is not a social animal but he is also an undeniable product of his environment and his surroundings. Ecocriticism has highlighted the awareness about the issues related to nature and environment. Now-a-days, because of the extreme influence of nature and its elements on living beings' environmental issues are in discussion. The survival of human beings is deeply connected with the existence of healthy environment. Both nature and human beings are effected by each other. Every human being has a significant role in the universe to protect nature. Ecocriticism provides such kind of platform on that humanists thoroughly discussed the connection between human beings and the natural world. They also discussed the effects of nature on human minds. They start a movement to create awareness about the importance of environment in the lives of human beings and under the theory named Ecocriticism. It is an investigation of the connection between nature and human beings as well as it is also concerned how that connection is depicted in literature. It is also an investigation of the raising environmental problems as well as cultural issues that are causing environmental issues. Ecocriticism also deals with the human behavior towards nature and how an individual reacts to ecological concerns. In this theory the emphasis is not only on human beings but also gives importance to non-human characters and the connection between them. First of all, it deals with the interest of human beings in literature. Because of this theory, nature became valuable in literature. The necessary thing of ecocriticism is to deal with the existence of human as well as non-human characters in the literature. Ecocritics not only consider human beings as an important part of literature but they also give importance to non-humans in literature. In fact, the aim of ecocriticism is to investigate the interconnectedness of human beings with non-humans in literature. Ecocritical aspects can also be found in the works of the writers of ancient ages like in the Chaucer and writers of Renaissance, Romantic and Victorian ages. They were unconsciously using ecological aspects in their works. 
Ecocritical awareness was changed into the form of an association with the passage of time named as The Association of the Study of Literature and Environment known as ASLE. Then more work has been done in this field for instance the two important works like Cheryll Glotfelty's book The Ecocriticism Reader and Lawrence Buell wrote The Environmental Imagination. These works contribute a lot in the development of Ecocriticism.

According to Dr. Mark. C., the term ecology is a metaphor used to explain natural world and the term environment is used to define both natural and human world. In his interview to OSLE (Organization of the Study of Literature and Environment) he said that he liked the term environmental writing because he was concerned towards the experience of writers about nature and culture and for this purpose environment was the most accurate word. He was of the view that all cultures exist in the natural world that is why all actions of human beings towards natural world are automatically their actions towards their culture.

Cheryll Glotfelty says that Ecocriticism is a key approach that investigates the connection between human culture and physical world. Both are deeply connected with each other. Ecocriticism not only deals with connection between culture and nature but it also investigates the objects of culture that effects literature. This very point differentiates Ecocriticism from anthropocentricism because anthropocentricism says that human beings are most essential and powerful on earth than anything else. On the other hand, Ecocriticism gives equally gives importance to human beings as well as ecosystem (or nature). It is of the view that both human beings and nature are important and have a deep connection.

The interconnection between environment and nature is the subject of Ecocriticism, especially it deals with the cultural articrafts of language as well as literature. "As a critical stance, it has one foot in literature and the other on land; and as a theoretical discourse, it negotiates between the human and non-human." (Glotfelty \& Fromm, 1996, p. 19)

Ecocriticism was first appeared in the form of a theory like other theories as Feminism, Marxism in the work of Cheryll Glotfelty (1996) The Ecocriticism Reader. This was the first complete book on ecocriticism that deals with major points of Ecocriticism. In this book ecocriticism is discussed from its emergence to its present shape. Glotfelty also describes the difference between the terms eco and enviro as the prefixes. She says that enviro deals with humans and places them as a center that are surrounded all other things. On the hand, the term eco focuses on nature and culture and consider them as an interconnected term and called it the major aspect of ecology of earth. In this way, Ecocriticism is defined as well as explained by Glotfelty. The role of Ecocriticism in shaping cultural and natural point of view is also discussed. 
Literature itself also plays a great role to develop a strong connection between nature and culture of human society as well as man's relation with nature. The aim of the critics of Ecocriticism is to study those texts in which the connection between man and nature is highlighted. The concern of Ecocriticism is to investigate the connection between human beings and environment and it is equally important for the theory to study the behavior of human beings towards nature.

Meeker's (1974) The Comedy of Survival an important book that focuses on the importance of Ecocriticism and deals with the causes that are the reason of environmental crisis. He is of the view that tradition of the western world spreading such type of culture that separates culture from nature and deprives nature from moral prevalence. Meeker says that "Comedy illustrates that survival depends upon our ability to change ourselves rather than our environment, and our ability to accept limitations rather than to curse fate for limiting us." (Meeker, 1974, p. 21). This work contributes a lot in Ecocriticism, it is said that comic mood provides recovery on the other hand destruction is caused by tragic moods in the western society.

Watson (2007) Back to Nature: The Green and the Real in the Late Renaissance has investigated the ecocritical elements in the works of Shakespeare and other writers of renaissance age. Romadhon (2011) in his investigation entitled as An Analysis of Environmental Issues using Ecocriticism in James Comerson's film Avatar studies the connection of human beings and non-humans with nature.

Ghosh's (2005) The Hungry Tide is a novel that has revealed the connection among the state, the poor, the fauna and flora and the environment. In this novel, Ghosh is highlighting the stiffness between human communities and their relations with natural world. There has been discussed a conflict between human beings and nature. The dispute is between the inhabitants of Sunderbans and the aquatic as well as wild life. The landscape of country is harsh and full of death, "at no moment can human beings have any doubt of the terrain's hostility, to their presence of its cunning and resourcefulness, of its determination to destroy or expel them. Every year dozens of people perish in the embrace of that dense foliage, killed by tigers, snakes and crocodiles." (Ghosh, 2005, p. 7).

\section{Material and Methodology}

The research methodology of the present study would be the textual analysis of Coelho's The Alchemist from an ecocritical point of view and for this purpose we sought help from the online resources and libraries. The published articles were also consulted. Further the study was conducted through the analysis of the text with the perspective of ecocriticism. 


\section{Sample}

Sample of study is the text of the novel The Alchemist and the secondary source are the books, articles, internet and journals.

\section{Type of Research}

The research is qualitative in nature.

\section{Implications and delimitations}

The novel, Alchemist, was selected in this study to highlight the key role of Ecocriticism due to the vital impact of environment on the lives of living creatures on the earth. The study is delimitized up to only the study of the key notions of the theory of Ecocriticism.

\section{Conceptual Framework}

In the meetings of Western Literature Association in 1970's, the concept of Ecocriticism was first roused. Although the essay of William Ruckert (1978) Literature and Ecology: An Experiment in Ecocriticism is considered the initiative of ecocriticism. Ruckert's major focus in the essay was on the concepts of ecology and its application in literature. In 1980s in America and in 1990s in Britain the terms ecocriticism and green studies became popularized. It throws light on the significance of nature in shaping the characters of individuals, studies different cultures, different languages as well as influence of nature on society. One of the aims of Ecocriticism is to unveil those actions of human beings which destroy the nature. Industrial wastages, factory pollution and destruction of ozone layer are the factors that destroy the nature and create disturbance in ecosystem.

Ecocritics put emphasis on reshaping the concepts of human beings about nature and focus on saying that nature is an active and speaking object of universe and has a significant role in the universe. Despite the broad scope of inquiry and disparate levels of sophistication, all ecological criticism shares the fundamental premise that human culture is connected to the physical world, affecting it and affected by it. Ecocriticism takes as its subject the interconnections between nature and culture, specifically the cultural artefacts of language and literature. As a critical stance, it has one foot in literature and the other on land; as a theoretical discourse, it negotiates between the human and the non-human.

Cheryll Glotfelty (1996) defines ecocriticism in his book The Ecocriticism Reader: Landmarks in Literary Ecology as: "The study of the relation between literature and the physical environment." This definition of ecocriticism is the most widespread definition. Lawrence Buell (1995) defines ecocriticism in his book The Future of Environmental Criticism: Environmental Crisis and Literary Imagination as "the 
environmentally oriented study of literature and arts more generally, and to the theories that underline such critical practice."

There are so many debates on the issue of including human culture in the physical environment. In spite of the comprehensive opportunity of investigation all the criticism related to ecology shares the basic idea that human culture is in connection with the physical world, they both are affected by each other.

Dr. Mark C. Long in an interview found on OSLE India's Newsletter, in this framework, differentiates between ecology and environment. He is of the view that humanists used ecology as a metaphor in order to describe the nature and its elements. In this way, ecology is an idea of dealing with nature. Instead of it, environment is a comprehensive term that deals with the worlds of both humans and natural. He states that he has used the term of environment instead of nature writing because he was interested in those writings that focuses on natural and cultural ideas. It is said that human beings produce their culture according to their needs while on the other hand nature is not the production of human being that is why nature avoids the fact that the culture of human beings also exist in the natural world. The human beings owe our very existence to its processes. That is the reason that all of our actions are automatically an action towards ourselves as well as towards our culture.

Ecocriticism is such an approach that is different from other literary approaches of literature. The critics investigate the material, global, local, physical, historical ideas in literary works. The ecocritical theory is an interdisciplinary approach that deals with environmental studies, natural sciences, cultural studies and social studies. The roots of the word eco has been taken from the Greek word Oikos which has the meaning of house. Just as the word economy is the name of the management of house ecocriticism is the criticism of house means one is the management of the house and other is the study of the house. But the definition of house, or oikos, is not simple.

Nature in each case responded and responds to human interference. As an autonomous actor it can no longer be depicted as a mere setting, but becomes a protagonist capable of articulation... The land, for example, is more generally, a place, subtly or explicitly influences the psyche and the actual behavior of individual protagonists. Climate, wilderness condition, technologically altered landscapes, topographies and many other environmental elements- never as pristine nature, never as mere text function as a powerful force that human beings have to and do react to.

Paulo Coelho's The Alchemist will be analyzed from the perspective of above said theoretical frame of work or concepts 


\section{Literary Analysis}

Nature is a supreme thing and human beings depend on nature for everything. Ecocriticism focuses on the relationship between human and non-human characters and explains how human consciousness is formed by environment.

Literary world is full of the stories that highlights the beauty of nature. Both nature and culture always go hand in hand, if there is a story then there is surely the presentation of nature in that story even to a smaller extent but presentation of nature is there. The theory of Ecocriticism is not only highlighting the issues of the preservation of environment but also emphasizing the bond and harmony of human beings and nature. This theory highlights that human beings and non-humans have not only the strong bond between them but also connected with each other as the culture of human beings is connected with their physical environment.

The novel Alchemist has explained a great connection between universe and individual soul. This novel explores that divinity spread out all objects of nature and the union of ultimate soul is the purpose of human life. In this novel it is explained that the satisfaction of human soul can be achieved through the consciousness of the beauty of natural world. There is a corresponding relationship between environment and its living beings. There is a philosophy behind the story of the novel that is about the elements of earth and the relationship between human beings and elements if earth.

Man feels certain kind of peace and satisfaction in the lap of nature. He can't feel this peace usually but when he notices this and pay attention to it he feels a strong connection between himself and the environment around him. Nature and all its elements either water, plants, clouds, sun or desert helps a person to realize and then achieving his destination. As Coelho says, "When you really want something, the whole universe conspires in helping you to achieve it". (Coelho, 1988 p. 23)

Environment deeply effects the human beings and it has a great influence on human mind as well as his heart,

The boy was surprised at his thoughts. May be the church with the sycamore growing from within, he had been haunted. It had caused him to have the same dream for the second time and it was causing him to feel anger towards his faithful companions. (Coelho, 1988, p. 7).

Nature helps a person to realize his personal legend. When Santiago, the protagonist of the novel travelled around the world, he realizes his personal legend and purpose of life through travelling. He has visited so many places. He always sought a new road to travel. He traveled with his herd and here the phenomena of life attract life is experienced by the Santiago. "The world was huge and 
inexhaustible; he had only to allow his sheep to set the route for a while and he would discover other interesting things". These same things happen in the desert with the boy when alchemist asked him about to search life in the desert, then he free his horse. The horse stopped a place and there is the life, a snake was there. But the difference between human beings and animals is that human beings realize the new things happening around them or the change in environment but animals can't.

“The problem is that they don't even realize that they are walking a new road every day. They don't see that the fields are new and seasons change. All they think is the food and water." (Coelho, p. 11)

Santiago always thinks about the changes in the world and his atmosphere. He has the quest to know about the soul of the universe, that is the base of his destination and that base helps him to connect with the natural elements. That very base plays a great role in the development of his soul. In the abandoned church, he saw a dream twice and disturbed by his dream. Now, he decided to know the truth of his dream so he went to a gypsy woman who is considered to interpret the dreams. Dreams are the language of the God. Through dreams God communicate and gives the signals to his creatures.

The boy had a dream that a child took his hand and transported him to the Egyptian Pyramids and says to him that if he come there he will get his treasure. He describes his dream to the Gypsy woman;

I dreamed that I was in the field with my sheep, when a child appeared and began to play with the animals. I don't like people to do that, because the sheep are afraid of strangers. But children always seem to be able to play with them without frightening them. I don't know why. I don't know how animals know the age of human beings. The children went on playing with my sheep for quite a while and suddenly the child took my both hands and transported him to the Egyptian pyramids. Then at the Egyptian pyramids the child said to me, "if you come here you will find a hidden treasure". (Coelho, 1988, p. 13-14)

He is following his heart. His heart always talks to him. It is considered that his heart is telling him the truth of the universe as well as about his own self. His heart helps him to interpret and understand his dream. His heart teaches him things through signs. His dream is also a kind of sign. And he always tries to understand these signs whether he is sleeping or awakening. When he is in the desert after meeting with Fatima, he feels sleepy but he understands the sign his heart has shown him. This sign is about the war in the oasis. His heart is in connection with desert and every element of nature. That's why he has shown the true image of future, the future of oasis. Here, we can see a strong relationship between his heart and desert. 
"He felt sleepy. In his heart, he wanted to remain awake but he also wanted to sleep. I am learning the language of the world, and everything in the world is beginning to make sense to me, even the flights of hawks, he said to himself." (Coelho, 1988, p. 104)

Now Santiago's vision has become very active and he senses and interpret what his heart telling him. He focusses is on his surroundings. Even he is in the desert but he has a very strong connection with this natural element and because of this relationship he is now able to understand what nature says to him through his heart's voice. This is the Soul of the world whom he is in contact with. He realizes that the requirement of the Soul of the world is to understand what the world is going to give him.

Santiago has faced so many problems and threats in his life but he always conquers them with his knowledge and his efforts. His knowledge is to learn the language of the world, and this knowledge is also his treasure that is named personal legend by Coelho. Because of this knowledge, he is able to develop his deep relationship with nature and its elements. Desert helps Santiago to learn the language of the soul. It could not stop learning to him, even it helps him to hear the voice of his heart. He keeps learning as long as it is useful for his life and his journey towards his treasure.

I learn that the world has a soul, and that whoever understands that soul, can also understand the language of things. I learn that many alchemists realize their destinies, and wound up discovering the soul of the world, the Philosopher's Stone, and the Elixir of life. But above all, I learned that these things are all so simple that they could be written on the surface of an emerald. (Coelho, 1988, p. 87)

There is another example of this close relationship between man and nature. When Santiago's soul is silent everything in the world seems to him silent. The boy's soul is silent because he has lost all his money, his sheep and he has to work in a crystal shop to earn his livelihood and to get back his sheep.

"There was a moment of silence so profound that it seemed the city was a sleep. No sound from the bazaars, no arguments among the merchants, no men climbing to the towers to chant. No hope, no adventure, no old kings or destinies, no treasure, and no pyramids. It was as if the world has fallen asleep as if the boy's soul had." (Coelho, 1988, p. 49).

The boy's soul is silent because he has lost all his money, his sheep and he has to work in a crystal shop to earn his livelihood and to get back his sheep. All elements of universe helps him in finding his treasure even stones, wind, sun, desert, hawks, moon, horse, gold and crystals etc. 
Stones play a role like omens for him. The old king gave him two stones called Urim and Thummim. They are black and white in color. Black means yes and white means no. Old king has told him that boy could use them to ask simple questions like should he do this work or not? Stones are also the part of nature. These stones are his first treasure that help him to proceed further. First time in his life, he got courage from his stones being a part of nature.

"Take these", said the old man, holding out a white stone and a black stone that had been embedded at the center of the breastplate. "They are called Urim and Thummim. The black signifies 'yes' and white 'no'. When you are unable to read the omens, they will help you to do so. Always ask an objective question. (Coelho, p. 31). "They are called Urim and Thummim, and they can help you to read the omens." (Coelho, 1988, p .43).

The boy is crossing the desert to find his treasure. His friend alchemist has told him that with the help of listening the voice of your heart and focusing on earth, he will understand the world as well as the desert and its language which leads him to understand the soul of the world.

"So immerse yourself in it. The desert will give you an understanding of the world; in fact, anything on the face of the earth will do that. You don't even have to understand the desert: all you have to do is contemplate a simple grain of sand, and you will see in it all the marvels of creation." (Coelho, 1988, p. 134).

As we see or assumes the nature, it treats us like that. For example, if we see nature as our friend and finds attractive and interesting things in it, it seems to us a very attractive, friendly and most interesting and it will help us to reach our destination. This thing can be proved by the examples of the character of Eustacia from The Return of the Native, to her the atmosphere of Egdon Heath is very precarious and she always hates Egdon Heath, then the result is that she cannot get any kind of favor from the very atmosphere or nature. It's because of her thinking that was negative towards nature. On the other hand, Santiago feels a certain kind of fellowship with nature even in Tarifa and in desert also. He finds nature his helper. That's why, nature and the whole universe helps him in finding his destination. The more one closes to nature, the more universe helps him. "Most people see the world as a threatening place, and, because they do, the world turns out, indeed, to be a threatening place." (Coelho, 1988, p. 138).

The title of the novel is also very significant and has a deep relationship with the nature. When Santiago and alchemist were crossing the desert, they were caught by the tribesman who allegated them as spies. Alchemist introduced the boy to tribesman as an alchemist. Then he gives the definition of alchemist in front of boy. He says; "A man who understands the nature and the world" (Coelho, 1988, p. 146). 
Alchemist here also reveals the personality of the boy and exposes his inner personality with all his qualities. He says to tribesman that;

"It's a man who understands nature and the world. If he wanted to he could destroy this camp just with the force of wind." (Coelho, 1988, p. 147)

The boy was feeling afraid because he says that he does not know how to change himself into the wind. Then the alchemist encourages him by saying that, "Remember what I told you: the world is only visible aspect of God. And what alchemy does is to bring spiritual perfection into contact with the material plane" (Coelho, 1988, p. 150). Here he tries to say him that through nature we are in contact with God and alchemy means relationship with nature through alchemy human beings got spiritual perfection. It means spiritual perfection can be achieved through nature.

To reach his destination or to find his treasure the boy had to cross the desert and now desert can only be pass by turning himself in to the wind in front of the tribesman. And now the time comes when he contacts with natural elements and practice this connection. Now the desert is talking to him; "What do you want here today?" the desert asked him. "Did not you spend enough time looking at me yesterday?" (Coelho, 1988, p .151)

Here Coelho shows the consequences of this relationship and it can be called a reward of this relationship. Now desert and boy are talking to each other. Both are understanding each other's language because it's the language of the Soul of the world and both human beings and nature are the product of the same soul. They are deeply connected with each other, either human beings pay attention to it or not but nature has its signification in man's life. Coelho here tries to show this connection through the practical of Santiago. Desert knows that the very person was looking at him and what are his feelings, motives and what he wants? Now the boy is started to making arguments with the desert and he demands to fulfill his wish from the desert because he also has the believe that it will understands him. He has this firm believe because he also tries his best to understand what desert or nature tries to say human beings. He says to him;

"Somewhere you are holding the person I love, the boy said. "So when I looked out over your sands, I am also looking at her. I want to return to her, and I need your help so that I can turn myself into the wind." (Coelho, 1988, p .151-152)

Now the desert asking him about love and boy replies to it by telling it's the whole game of falcon which the desert knows very well and enjoys a lot. Both Falcon and the desert have a deep relationship with each other. Desert nourishes the falcon and then falcon nourishes the man and at the end, man nourishes the sands of the 
desert by travelling through it. The whole process is about love, love of the Soul of the world.

The wanted to turn himself into the wind and asking help from the desert. After the above dialogue with the desert, it says that alone it can do nothing, the boy should ask from the wind to help him. "I'll give you my sands to help the wind to blow, but, alone, I can't do anything, you have to ask for help from the wind." (Coelho, 1988, p. 153).

Here Coelho, by giving words to natural elements showing the deep connection between nature and human beings. Now, a breeze started to blow. Here the wind plays its role and showing its relationship with human beings. The boy started to talk with the wind and asks him to help him by saying that once it gave him the signal about his journey in the desert when he was in Tarifa before working in crystal shop. When he first met with Melchizedek, the king of Salem.

\section{Conclusion}

In conclusion, we can say that Coelho in his novel The Alchemist tries to show the deep connection between the human beings and nature. He shows how the lives of human beings are interconnected with nature. The present research is the evidence of this strong connection between nature and human beings as well as the relationship between literary text and the atmosphere. It shows "the relationship between the literature and physical environment." (Glotfelty, 1996, p. 18) Through this research it is explored that there is a symbiotic relationship between human mind and nature. The story of the novel is filled with the power of nature that helps a person a lot in reaching his destination. Nature is operating by laws in order to keep balance and discipline according to God's will; love and through its procreation was one of these laws possibly the highest of them as Coelho suggests in text by discussing the force of love and in the dialogue of Santiago with sun, desert and wind. All the elements of nature have their own importance and value as well as they play their functions. All elements of nature are connected in order to keep the balance and order of the universe. The meaning of the quote of the writer Paulo Coelho is proved through this research that is "when you really want something, the whole universe conspires it in your favor." 


\section{References}

Barry, P. (2008). Beginning Theory: An Introduction to the Literary and Cultural Theory. New Delhi: Viva Books.

Carson, R. (1962). Silent Spring. Houghton Mifflin.

Coelho, P. (1988). The Alchemist. Brazil: Herper Torch.

Gerrard, G. (2005). Ecocriticism. New York: Routledge.

Ghosh, A. (2005). The Hungry Tide. Harper Collins.

Glotfelty, C. \& Fromm, H. (1996). The Ecocriticism Reader: Landmarks in Literary Ecology. Athens: University of Georgia Press.

Love, G. A. (1996). The Ecocriticism Reader: Landmarks in Literary Ecology. Revaluing Nature: Toward an Ecological Criticism.

Love, G. A. (2003). Practical Ecocriticism: Literature, Biology and Environment. USA: University of Virginia Press.

Meeker, J. (1974). The Comedy of Survival: Studies in Literary Ecology. New York: University of Arizona Press.

Ruckert, W. (1996). The Ecocriticism Reader: Landmarks in Literary Ecology, Literature and Ecology: An Experiment in Ecocriticism. Athens: University of Georgia. 